\title{
Egg production rates of Calanus helgolandicus females reared in the laboratory: variability due to present and past feeding conditions
}

\author{
Catherine Rey-Rassat ${ }^{1, *}$, Xabier Irigoien ${ }^{2, * *}$, Roger Harris $^{2}$, Robert Head ${ }^{2}$, \\ François Carlotti ${ }^{3}$
}

${ }^{1}$ Université Pierre et Marie Curie (Paris VI), Station Zoologique, ESA 7076, CNRS/INSU, BP 28, 06230 Villefranche-sur-mer, France

${ }^{2}$ Plymouth Marine Laboratory, Prospect Place, Plymouth PLI 3DH, United Kingdom

${ }^{3}$ Laboratoire d'Océanographie Biologique, CNRS, Université Bordeaux 1, UMR 5805, 2 rue du Professeur Jolyet, 33120 Arcachon, France

\begin{abstract}
Four egg production experiments were performed under controlled conditions on Calanus helgolandicus females from laboratory cultures with a known history of feeding conditions. Two of the experiments were run with females from a cohort reared at a low concentration of Prorocentrum micans $\left(77.5 \mu \mathrm{g} \mathrm{C}^{-1}\right.$, Cohort L). One of the egg production experiments was run at the same low food concentration (females called LL) and the other one at high food concentration (females LH). Another 2 experiments were performed with females from a cohort reared at a high P. micans concentration $\left(278 \mu \mathrm{g} \mathrm{C} \mathrm{l}^{-1}\right.$, Cohort $\left.\mathrm{H}\right)$. One of these experiments was run at the same high food level (females $\mathrm{HH}$ ) whereas the other one was run at the low food concentration (females HL). These 4 experiments allowed us to estimate the influence of both present and past feeding conditions on the egg production rates of the females. The catabolism of the internal resources in terms of carbon (lipid) and nitrogen (protein) of the females was more important for those held at the low concentration and it also varied with the origin of the females. Females L, which had been food-limited during their growth (LL and LH), were apparently deficient in nitrogen since they lost twice as much carbon as nitrogen, whereas females $\mathrm{H}$ ( $\mathrm{HH}$ and $\mathrm{HL}$ ) drew equally on their carbon and nitrogen resources. After 7 to $10 \mathrm{~d}$, the egg production of females L was significantly lower than that of females $\mathrm{H}$, at both food concentrations ( $\mathrm{LL}<\mathrm{HL}$ and $\mathrm{LH}<\mathrm{HH}$ ). To explain these results, we propose that females $\mathrm{L}$ had a lower assimilation efficiency than females $\mathrm{H}$ and that, even if they had a higher specific ingestion rate at the beginning of the experiment, they were not able to compensate for metabolic deficiencies (e.g. in protein). Our results indicate that the feeding history of the females may be important in explaining the egg production values found in the field since in situ food conditions are unlikely to remain optimal during an entire generation.
\end{abstract}

KEY WORDS: Calanus helgolandicus - Female - Egg production rate · Food concentration · Feeding history

Resale or republication not permitted without written consent of the publisher

\section{INTRODUCTION}

In situ egg production is increasingly used to estimate the growth rates of planktonic copepods and

\footnotetext{
*E-mail: catherinerey@aol.com

${ }^{* *}$ Present address: AZTI, Herrera Kaia portualdea z/g, 20110

Pasaia (Gipuzkoa), Spain)
}

these growth rates are often extrapolated to all the stages of the species (Kiørboe \& Nielsen 1994, Hay 1995, Calbet \& Agusti 1999, Irigoien et al. 2000a). Egg production is a relatively simple measurement to make on cruises compared to the estimation of juvenile growth (Peterson et al. 1991). However, to fully understand the results, it is important to keep in mind all the factors that may influence egg production measure- 
ments. Environmental factors (mostly temperature, food concentration and food quality) measured at the same time as spawning are those which are the most frequently reported in the studies to explain variation among egg production rates found at different times or in different areas (Plourde \& Runge 1993, Hay 1995, Calbet \& Agusti 1999, Niehoff et al. 1999, Harris et al. 2000, Irigoien et al. 2000a).

During the last decade, some authors have suggested that the past environmental conditions could also be important in understanding the in situ variation of physiological rates (Båmstedt 1988, Båmstedt \& Tande 1988, Donaghay 1988, Huntley 1988, Attwood \& Peterson 1989, Lopez 1991, Huntley \& Lopez 1992). These authors have pointed out the necessity of studying the influence of past conditions in more detail; however, very few studies have been carried out since. To estimate such an effect on the female egg production rate, 2 kinds of experiments can be performed in the laboratory. First, short-term history can be assessed by modifying environmental conditions during egg production experiments and comparing the results with controls where conditions remain stable. A certain number of studies have been carried out following this protocol (Runge 1984, Frost 1985, Attwood \& Peterson 1989, Nival et al. 1990, Carlotti \& Hirche 1997, Hirche et al. 1997, Båmstedt et al. 1999). In most of the cases, food concentration was modified during the experiment in order to mimic the field situation in which the females do not encounter homogeneous food concentration but rather patchily distributed food.

Second, to estimate experimentally the influence of past conditions, the egg production rate of females can be measured in environmental conditions different from those used during their juvenile growth. Indeed, this scenario probably corresponds to that most frequently found in the field since the environmental conditions often change over 1 population generation time. The problem raised in our study is to know whether the egg production rate is simply the consequence of recent environmental conditions encountered by the females or if it depends also on their own body characteristics (size, biochemical contents), which are the result of their past growth history. Such investigations, which are rare in the literature (Rey et al. 1999), require a lengthy experiment in which the environmental parameters are controlled from hatching to the spawning of the resultant adult females. Our experiments were done on Calanus helgolandicus, a dominant copepod species in the North Atlantic, reared in the laboratory under different food concentrations. The egg production rates as well as other physiological body characteristics were measured individually for $20 \mathrm{~d}$ on females with different growth histories.

\section{MATERIALS AND METHODS}

Origin and fertilization of the females. The Calanus helgolandicus females used in our experiments came from 2 cohorts L (low food level) and H (high food level) reared as described in Rey-Rassat et al. (2002, this volume). Briefly, each of these cohorts was raised from eggs spawned within $12 \mathrm{~h}$ by wild females collected from Stn L4 $\left(50^{\circ} 15^{\prime} \mathrm{N}, 4^{\circ} 13^{\prime} \mathrm{W}\right)$, which is approximately $10 \mathrm{~km}$ off Plymouth, western English Channel (Table 1). These eggs were then transferred into $15 \mathrm{l}$ glass beakers filled with a suspension of Prorocentrum micans adjusted to 200 cell $\mathrm{ml}^{-1}$ every $12 \mathrm{~h}$, up to Day 10 (Day 0 is defined as the time when $50 \%$ of the eggs were spawned). Subsequently, 3500 individuals (mostly at the copepodite stage $\mathrm{CI}$ ) were transferred to a 150 l polyethylene tank filled with a suspension of $P$. micans. The 2 cohorts isolated individually in a $150 \mathrm{l}$ tank were finally reared at 2 different $P$. micans

Table 1. Calanus helgolandicus fed on Prorocentrum micans. Summary of the nutritional conditions of the females during their past growth and during the 4 spawning experiments run with the Females LL (i.e. low food when growing, low food when spawning), $\mathrm{LH}, \mathrm{HH}$ and HL. During all their life, the females were fed on $P$. micans but at different cell concentrations (cell ml ${ }^{-1}$; checked every $12 \mathrm{~h}$ ). The day $t=0$ is defined as the time when $50 \%$ of the eggs were spawned (the eggs were spawned within $12 \mathrm{~h}$ ). Tf corresponds to the time when the first fertilized females were found in the tanks. In Tank L, the 40 females required for the spawning experiments were found on Days 44 and 45, and in Tank H, the 40 females were found between Days 29 and 34 (the geometric mean is 32)

\begin{tabular}{|c|c|c|c|c|c|c|}
\hline \multirow{2}{*}{\multicolumn{2}{|c|}{$\begin{array}{l}\text { Process: } \\
\text { Stage: }\end{array}$}} & \multicolumn{2}{|c|}{ - Growth } & \multicolumn{3}{|c|}{ - Spawning } \\
\hline & & Nauplii & Copepodites & \multicolumn{3}{|c|}{ Adults } \\
\hline \multicolumn{2}{|l|}{ Place: } & 151 beaker & $150 \mathrm{ltank}$ & \multicolumn{3}{|c|}{$280 \mathrm{ml}$ spawning beaker } \\
\hline \multicolumn{2}{|c|}{ Time (d): } & \multicolumn{2}{|c|}{$0 \longrightarrow 10$} & \multicolumn{3}{|c|}{$\mathrm{Tf} \longrightarrow \mathrm{Tf}+10 \longrightarrow \mathrm{Tf}+15 \longrightarrow \mathrm{Tf}+20$} \\
\hline \multirow[t]{4}{*}{ Expts: } & LL & \multirow{4}{*}{200 cell ml ${ }^{-1}$} & \multirow{2}{*}{50 cell ml $^{-1}(\mathrm{~L})$} & 50 cell ml $^{-1}(\mathrm{~L})$ & \multicolumn{2}{|l|}{60 cell ml $^{-1}(\mathrm{~L})$} \\
\hline & $\mathrm{LH}$ & & & 180 cell ml $\mathrm{m}^{-1}(\mathrm{H})$ & & 240 cell ml $\mathrm{m}^{-1}(\mathrm{H})$ \\
\hline & HL & & \multirow{2}{*}{180 cell ml ${ }^{-1}(\mathrm{H})$} & 50 cell ml $^{-1}(\mathrm{~L})$ & 60 cell ml$^{-1}(\mathrm{~L})$ & \\
\hline & $\mathrm{HH}$ & & & 180 cell ml $^{-1}(\mathrm{H})$ & & 240 cell ml ${ }^{-1}(\mathrm{H})$ \\
\hline
\end{tabular}


concentrations, a low (50 cell $\mathrm{ml}^{-1}$, Cohort L) and a high one (180 cell ml ${ }^{-1}$, Cohort $\left.\mathrm{H}\right)$.

Because we wanted to follow the egg production rates of the females, we needed fertilized females at the end of both cohort developments. However, fertilization of Calanus sp. females in the laboratory is difficult to achieve because males are rarely found in Calanus cultures (Peterson 1988, Irigoien et al. 2000c) and also because the mating success under rearing conditions is rather low (Tsuda \& Miller 1998), which contrasts with rearing performed in in situ mesocosm enclosures (Hygum et al. 2000). In one of our cohorts (Cohort L), no males were found and we were forced to introduce wild males isolated from samples collected at Stn L4 once most of the CVs had moulted into females (50 males on Day 36 and 100 males on Day 40). The first fertilized females were found around $10 \mathrm{~d}$ either after the introduction of males in the case of Cohort L or after the appearance of the first adults in the case of Cohort H. However, in both cohorts, the percentage of the fertilized females was very low $(\sim 10 \%)$. In the case of Cohort L, the fertilized females used for the experiments were found on Days 44 and 45 and in the case of Cohort H on Days 29 to 34 (the geometric mean is 32). This means that the females from Cohort L were older than those from Cohort $\mathrm{H}$ at the start of the experiments. This comes from the fact that the appearance of the females in the Cohort L was later than in the Cohort $\mathrm{H}$ (due to slow development of the Cohort L, see Rey-Rassat et al. 2002) and that the collection of wild males (required to fertilize the females L) had been delayed due to a problem with plankton collection. The first fertilized females found in both cohorts were used for egg production experiments, the following ones were used to run ingestion experiments.

Egg production experiments. Fertilized females collected from both Tanks $\mathrm{L}$ and $\mathrm{H}$ were held individually in $280 \mathrm{ml}$ spawning cylinders made of Plexiglas with $400 \mu \mathrm{m}$ mesh false bottoms suspended in $400 \mathrm{ml}$ beakers filled with a Prorocentrum micans suspension (Table 1). Twenty replicates from Cohort L were incubated at the same low concentration L (Females LL), and 20 others at the high concentration $\mathrm{H}$ (Females LH). In a similar way, 20 females from Cohort $\mathrm{H}$ were incubated at concentration $\mathrm{H}$ (Females $\mathrm{HH}$ ), and 20 others at concentration L (Females HL).

The dinoflagellate Prorocentrum micans (26.6 $\mu \mathrm{m}$ equivalent spherical diameter) used in our experiment was grown in a 101 semi-continuous culture using f/2 medium under a 12:12 h light:dark cycle (for more details see Rey-Rassat et al. 2002). The cell concentration was estimated by 3 cell counts made with a Coulter Multisizer, fitted with a $100 \mu \mathrm{m}$ orifice tube. $P$. micans was chosen because of its motility and good nutritional value. During experiments we tested how the egg production rate of the females responded to slight variation of the food supply and, for that purpose, we increased the food concentration as follows (see also Table 1): (1) for the low concentration L, from 50 to 60 cell ml-1 $10 \mathrm{~d}$ after the first experimental day; and (2) for the high concentration $\mathrm{H}$, from 180 to 240 cell ml $\mathrm{m}^{-1}, 15 \mathrm{~d}$ after the first day.

All the females were maintained at a constant temperature of $15^{\circ} \mathrm{C}$, which also corresponds to the temperature that they encountered during their growth.

Each day, each cylinder containing 1 female was quickly placed in a new beaker with fresh food. Eggs and fecal pellets produced during the previous $24 \mathrm{~h}$ were counted under a dissecting microscope. After $20 \mathrm{~d}$ of experiments, each female was first isolated on a GF/C filter in order to determine its prosome length, oil sac volume and the stage of gonad maturity. Then, each female was transferred to an aluminum cup and stored at $-25^{\circ} \mathrm{C}$ for later carbon and nitrogen analysis.

To have an idea of the condition of the females when the egg production experiments were started, we also determined the prosome length, the oil sac volume and the carbon and nitrogen content of the fertilized females that were used in the ingestion experiments.

Hatching success and ingestion rates. The hatching success of the eggs was estimated by collecting the eggs laid within $24 \mathrm{~h}$ by each female for the 4 different categories (LL, LH, HH and HL) and by incubating them at $15^{\circ} \mathrm{C}$ in Petri dishes filled with filtered seawater. The hatching success was measured after $72 \mathrm{~h}$ by counting the dead eggs (all the abnormal nauplii were considered dead). This estimate of the hatching success was made $10 \mathrm{~d}$ after the start of each experiment (or the day after, if the female had not spawned at this time).

The ingestion rates of the fertilized females were measured in 4 experiments corresponding to the 4 categories of females considered in the egg production experiments. Groups of 4 females were placed in 2.51 bottles filled with a suspension of Prorocentrum micans (either low or high concentration). Four replicates with females and 4 controls without animals were used for each experiment. The 8 bottles were incubated on a rotating wheel $(0.2 \mathrm{rpm})$ for $24 \mathrm{~h}$. The cell concentration at the beginning and end of the experiments was measured using a Coulter Multisizer. Filtration and ingestion rates were calculated following Frost (1972).

Data analysis. The wax ester content was estimated from the volume of the oil sac (for details see Rey et al. 1999). The volume (in ml) was transformed into wax ester (in gC) by (1) multiplying it by the density of $0.86 \mathrm{~g} \mathrm{ml}^{-1}$ (Sargent \& Henderson 1986), (2) multiplying it by the ratio of the carbon content in wax ester 
of 0.78 (from Table 2.3 of Sargent \& Henderson 1986), and (3) dividing it by 1.44, a conversion factor coming from the fact that the wax ester content estimated from the oil sac volume was found to be 1.44 higher than that estimated from a calibrated Iastroscan, in Miller et al. (1998, from their Fig. 6). The stage of gonad maturity of the females was determined based on criteria described in Runge (1987). Reproductive index was calculated as the ratio of actively spawning females (in gonadal development stages 4 to 7 ) to the total number of females (Runge 1987, Plourde \& Runge 1993).

The female specific egg production rate $g_{\mathrm{f}}$ was calculated using the following equation:

$$
g_{\mathrm{f}}=W_{\text {eggs }} / W_{\text {female }}
$$

where $W_{\text {eggs }}$ is the total weight (in $\mu g \mathrm{C}$ or $\mu \mathrm{gN}$ ) of the eggs produced within $24 \mathrm{~h}$ and $W_{\text {female }}$ is the weight of the female (in $\mu \mathrm{gC}$ or $\mu \mathrm{gN}$ ). The chemical weight of a Calanus helgolandicus egg was considered to be $0.362 \mu \mathrm{gC}$ and $0.071 \mu \mathrm{gN}$ (Rey et al. 2001). These values were very close to those found by Pond et al. (1996, their Table 1). We also wanted to calculate the structural egg production rate, which can be estimated using the structural weight of the female (i.e. the total weight minus the weight of wax ester and the weight of the gonad) in Eq. (1), rather than the total weight of the female. As described by McLaren \& Leonard (1995), a female with a gonad full of ripe ovocytes, ready to spawn, is much heavier than a female that has just laid its eggs, whereas the production of both these females is the same. The spawning capacity of both these females depends on their structural weight. To solve this problem, we calculated the structural weight (in $\mu \mathrm{gC}$ ) of our females by using the allometric relationship established by Rey-Rassat et al. (2002):

$$
\text { Structural weight }=2.1329 \times 10^{-8} \times \text { Length }^{2.7925}
$$

Length is expressed in $\mu \mathrm{m}$. This relationship was obtained by subtracting the mass of wax ester (in $\mu \mathrm{g} C$ ) from the total body mass of carbon of all copepodite stages of Calanus helgolandicus (from CI to CV). A similar relationship was used by McLaren \& Leonard (1995) to calculate the female structural weight in $C$. finmarchicus. SDs for specific egg production rates were calculated according to the formula given by Takahashi \& Bienfang (1983) for a ratio (as the specific egg production rate is actually a ratio). This was not done in the case of the structural egg production rate because structural weights were not measured values but estimated values from length.

A general linear model (GLM) was built using SYSTAT 7.0 to test (1) whether the past feeding conditions had an effect on the egg production regarding the food condition used during the incubation and (2) whether this food treatment effect varied over the course of the 20 experimental days.

$$
\begin{aligned}
& \text { Egg production }=\beta 0+(\beta 1 \times \mathrm{PIF})+(\beta 2 \times \mathrm{IF})+ \\
& \quad[\beta 3 \times(\mathrm{PIF} \times \mathrm{IF})]+[\beta 4 \times(\mathrm{PIF} \times \mathrm{IF} \times \text { time })]+\varepsilon
\end{aligned}
$$

where $\beta$ is the coefficient of interaction, PIF is the preincubation food treatment, IF is the incubation food treatment, time is the number of experimental days and $\varepsilon$ is error. The significance level of the interaction terms (PIF $\times$ IF) and (PIF $\times$ IF $\times$ time) enabled the Questions (1) and (2) to be tested. A similar model was considered for fecal pellet production.

\section{RESULTS}

\section{Body characteristics of the adults}

The females from Cohort L were always significantly lighter and shorter than the females from $\mathrm{H}$ (Table 2).

Table 2. Calanus helgolandicus. Body characteristics of the fertilized females estimated at days close to the beginning of the spawning experiments (Initial) and at the end of the experiments (Final). All estimates are indicated as the mean \pm SD. Tests were

\begin{tabular}{|c|c|c|c|c|}
\hline Time & Length $(\mu \mathrm{m})$ & Wax ester ( $\mu \mathrm{g} C)$ & Carbon $(\mu g \mathrm{C})$ & Nitrogen $(\mu \mathrm{g} N)$ \\
\hline \multicolumn{5}{|l|}{ Initial } \\
\hline Females L & $2387 \pm 92$ & $1.6 \pm 7.5 \quad(\mathrm{n}=30 ; t=51)$ & $77.6 \pm 14.3$ & $11.7 \pm 2.1(\mathrm{n}=27 ; t=51)$ \\
\hline Females $\mathrm{H}$ & $2589 \pm 93$ & $11.4 \pm 16.5(\mathrm{n}=30 ; t=42)$ & $132.5 \pm 29.9$ & $24.3 \pm 1.3(\mathrm{n}=5 ; t=42)$ \\
\hline Test & $\mathrm{p}=0.00 \quad \mathrm{~s}$ & $\mathrm{p}=0.00 \quad \mathrm{~s}$ & $\mathrm{p}=0.00 \quad \mathrm{~s}$ & $\mathrm{p}=0.00 \mathrm{~s}$ \\
\hline \multicolumn{5}{|l|}{ Final } \\
\hline Females LL & $1928 \pm 75$ & $0 \quad(\mathrm{n}=20 ; t=64$ or 65$)$ & $43.3 \pm 12.4$ & $9.0 \pm 3.1(\mathrm{n}=19 ; t=64$ or 65$)$ \\
\hline Females LH & $1911 \pm 88$ & $0 \quad(\mathrm{n}=20 ; t=64$ or 65$)$ & $64.5 \pm 10.9$ & $14.7 \pm 3.5(\mathrm{n}=17 ; t=64$ or 65$)$ \\
\hline Test & $\mathrm{p}=0.50 \mathrm{~ns}$ & - & $p=0.00 \quad s$ & $p=0.00 \quad s$ \\
\hline Females HH & $2090 \pm 65$ & $\sim 0 \quad(\mathrm{n}=20 ; 49<t<54)$ & $83.9 \pm 17.5$ & $17.4 \pm 5.4(\mathrm{n}=18 ; 49<t<54)$ \\
\hline Females HL & $2097 \pm 62$ & $\sim 0 \quad(\mathrm{n}=20 ; 49<t<54)$ & $54.8 \pm 11.2$ & $11.4 \pm 3.5(\mathrm{n}=20 ; 49<t<54)$ \\
\hline Test & $\mathrm{p}=0.73 \mathrm{~ns}$ & - & $\mathrm{p}=0.00 \quad \mathrm{~s}$ & $\mathrm{p}=0.00 \quad \mathrm{~s}$ \\
\hline
\end{tabular}
done to determine the significant differences between 2 means (Z-tests for the length and the wax ester, and Kolmogorov-Smirnov tests for the carbon and nitrogen content). p: probability that means are equal; s or ns: the difference is significant or not at the $5 \%$ level; $\mathrm{n}$ : number of individuals; $t$ : day when the individuals are collected ( $t=0$ is the time when $50 \%$ of the eggs were spawn) 
Under different incubation conditions, females with the same origin had significantly different carbon and nitrogen contents, even if their prosome lengths were statistically the same (Table 2). The females from Cohort $\mathrm{H}$ which were incubated at the low food level (Females HL) had a much lower weight than those which remained at the high concentration (Females $\mathrm{HH}$ ). Inversely, the weight of the Females LH was much higher than those of the Females LL. The wax ester had been consumed in all the categories of females and only a few tiny oil droplets were visible in some of the females from Cohort $\mathrm{H}$. When the initial body characteristics of females were compared with those at the end of the experiments, their carbon and nitrogen content as well as their wax ester content was found to have greatly decreased. However, in 1 case (Females LH) there was an increase in the nitrogen content. Interestingly, the prosome length had also considerably decreased during experiments, which indicates the relative elasticity of the exoskeleton. In the future, this phenomenon needs to be checked by considering a greater number of individuals $(>20)$.
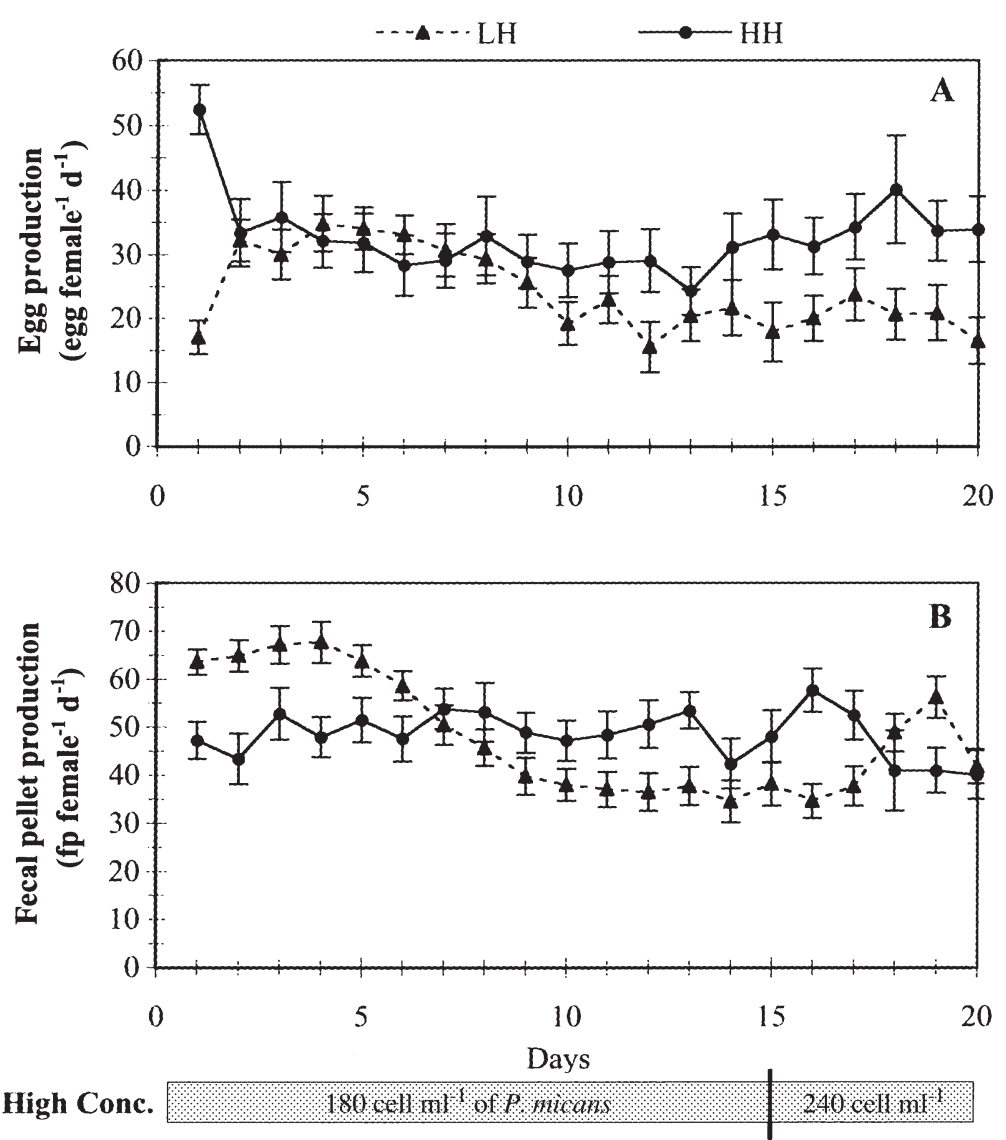

Fig. 1. Calanus helgolandicus. Mean egg (A) and fecal pellet (B) production with time during both spawning experiments run at the high Prorocentrum micans concentration ( $\mathrm{LH}$ and $\mathrm{HH}$ ). The high concentration increased slightly at Day 15. Vertical bars indicate SD

\section{Egg and fecal pellet production versus time}

The mean egg and fecal pellet production versus time was calculated for Females $\mathrm{HH}$ and LH (Fig. 1) and Females LL and HL (Fig. 2). The statistical model (Eq. 3 in 'Materials and methods') was used to analyze these data. In this analysis, the egg production and the egestion measured on Day 1 of each experiment were not considered because, for Females LH and HL, these values were the results of the food conditions encountered the day before (i.e. when these females were still at the food concentration used for their growth).

The significant model (coefficients of all terms were significant with $\mathrm{p}<0.05)$ was found to be: Egg production $=-15.28+(17.19 \times \mathrm{IF})+[4.03 \times(\mathrm{PIF} \times \mathrm{IF})]-[0.09 \times$ $(\mathrm{PIF} \times \mathrm{IF} \times$ time $)]$. Some conclusions can be pointed out from this model: (1) the coefficient of the term considering the incubation food concentration (IF) was significant and high, i.e. IF was the major effect to explain the egg production variability; (2) the coefficient of the interaction term $(\mathrm{PIF} \times \mathrm{IF})$ between IF and the preincubation food concentrations (PIF) was significant, i.e. the effect of the past feeding conditions on the egg production depended on the feeding condition used during the incubation. In other words, for each IF, the egg production of the females resulting from the 2 PIF was not the same; it happened to be higher for the females from the high PIF (in high IF: $\mathrm{HH}>\mathrm{LH}$; in low IF: HL > LL). This clearly indicates the effect of the past feeding conditions of the females on the egg production; and (3) the coefficient of the interaction term $(\mathrm{PIF} \times \mathrm{IF} \times$ time $)$ was significant, i.e. for each IF, the effect of past feeding conditions of the females on their egg production was time-dependent. The egg production decreased obviously with time in females LL and LH, whereas it did not in females $\mathrm{HH}$ and $\mathrm{HL}$.

In the case of the fecal pellet production, the significant model $(\mathrm{p}<0.05)$ was: Fecal pellet production $=-16.73+(4.06 \times \mathrm{PIF})+$ $(31.35 \times \mathrm{IF})-[0.13 \times(\mathrm{PIF} \times \mathrm{IF} \times$ time $)]$. Both variables PIF and IF had a significant effect on the fecal pellet production, but the interaction between both terms was not significant. In fact this latter result certainly derives from the fact that for both IFs the fecal pellet production of females resulting from the low PIF (Females LL and LH) became lower than that of females from the high PIF after some days of incubation (as was the case for the egg production), but then it increased again when the IF con- 

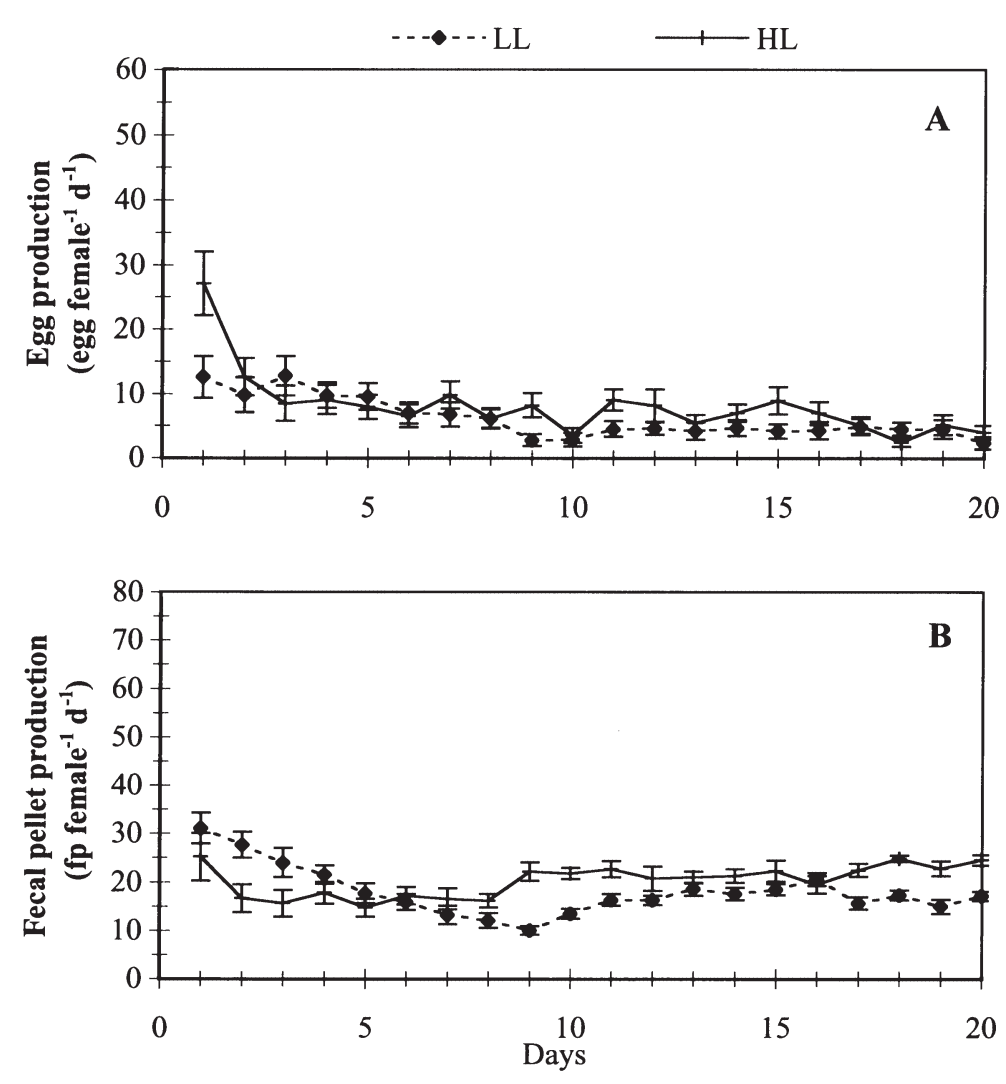

Low Conc.

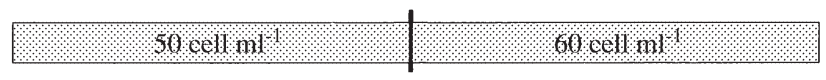

Fig. 2. Calanus helgolandicus. Mean egg (A) and fecal pellet (B) production with time during the 2 spawning experiments run at the low Prorocentrum micans concentration (LL and HL). The low concentration increased slightly at Day 10. Vertical bars indicate SD had spawned (at least 5 eggs) during the last $2 \mathrm{~d}$ of each experiment, we found that the majority had mature gonads when experiments ended $(55,73,88$ and $100 \%$ for Females LL, HL, LH and $\mathrm{HH}$, respectively) but others $(45,18$ and $6 \%$ for Females LL, HL and LH, respectively) had gonads which had already reverted to an immature stage. We also found 2 females with a senescent gonad. Concerning the females which had not spawned or produced $<5$ eggs during the last 2 experimental $d$, their gonads were still immature when the experiments were stopped, but in some cases their gonads had switched to a mature stage at the end of the experiments (14 and 33\% for Females LL and HL).

\section{Relationships between the female body characteristics and egg production rate}

In each of the experiments, we investigated the possible relationships between the different measurements made on the females (length, weight, egg production rate, egestion). We considered the different linear regressions between 2 of the variables (Table 3). There was a significant relation $(p<0.05)$ between carbon content versus the nitrogen content. The females which had the highest $\mathrm{C}: \mathrm{N}$ ratio were those which belonged to Cohort $\mathrm{H}$, correspond- centration was slightly increased (at Days 15 and 10 for the high and low IF, respectively), which was not the case for the egg production. Indeed, the effect of time on the fecal pellet production, regarding the PIF and IF concentrations, was apparent in the model with the interaction term $(\mathrm{PIF} \times \mathrm{IF} \times$ time $)$.

\section{Gonadal stage at the end of the experiments}

The reproductive index (RI), which is the frequency of the females with mature gonads (Fig. 3), was significantly different among the 4 categories of females $\left(\chi^{2}\right.$-test, $\left.\mathrm{p}<0.05\right)$. The highest RI was found for the females that were maintained at the high concentration $(\mathrm{HH}, \mathrm{LH})$. In terms of past feeding conditions, it was always the females resulting from Cohort $\mathrm{H}$ that had the highest RI (HH > LH, HL > LL); however, these differences were not significant $(\mathrm{HH}>\mathrm{LH}, \mathrm{p}=0.15$; HL $>$ LL, $\mathrm{p}=0.26$ ). When we looked at the females which

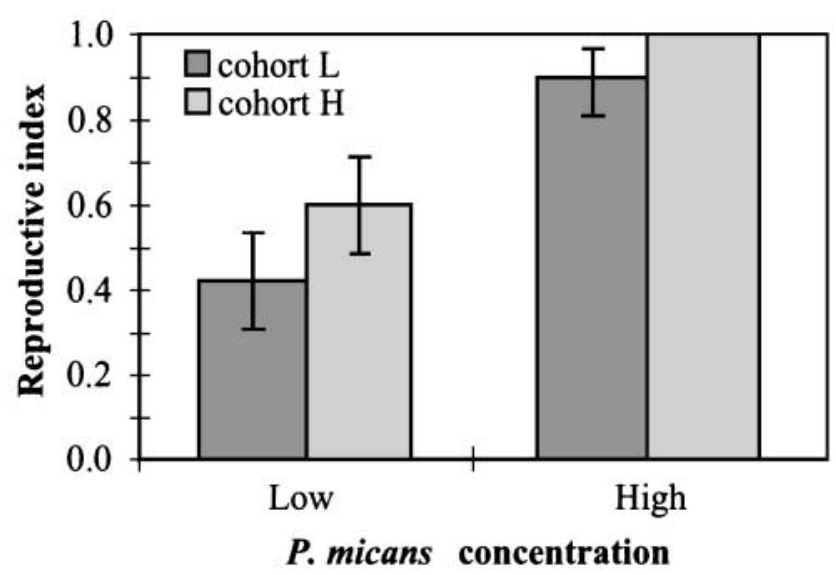

Fig. 3. Calanus helgolandicus. Reproductive index of the females determined at the end of the spawning experiments run at the high and low concentration. The reproductive index indicates the proportion of the females with a ripe gonad (see Runge 1987). Vertical bars indicate SD calculated for frequencies (note that for females $\mathrm{HH}, \mathrm{SD}=0$ since all the females were mature) 
ing to copepods which still had some oil droplets. The regression between carbon (or nitrogen) content versus the prosome length was significant for the females that were incubated at the high concentration (LH, HH). When we established logarithmic regressions between the carbon or nitrogen content and the size, the slopes of the regression represented the exponents of the allometric relationship relating the weight to the size. We found that the females incubated at the same concentration (low [LL, HL] or high [HH, LH]) had very similar relationships. The egg production rate was always strongly related to egestion but with different slopes each time. In contrast, egg production rate was never related to the prosome length of the females and only occasionally to the carbon and nitrogen content.

Table 3. Relationship between 2 measurements (the egg production, the fecal pellet production [pf]) or different body characteristics of a female, i.e. its prosome length (size), its carbon $(\mathrm{C})$ and nitrogen $(\mathrm{N})$ content, made on the females of each experiment (LL, LH, HH or HL). We also looked at the relationship found with the females held at the same concentration (Females $\mathrm{LL}+\mathrm{HL}$ and $\mathrm{HH}+\mathrm{LH}) . t$-tests are done to determine whether the slopes of each of the linear relationships are significant. If the slope is found significantly different from 0 at the $5 \%$ level, its value is indicated in the table. Otherwise, ns (not significant) is reported

\begin{tabular}{|lcccccc|}
\hline & LL & LH & HH & HL & LL+HL & HH+LH \\
\hline Slope C/N & 3.75 & 2.17 & 2.57 & 2.78 & - & - \\
Slope C/size & $\mathrm{ns}$ & 0.09 & 0.05 & $\mathrm{~ns}$ & 0.057 & 0.114 \\
Slope N/size & $\mathrm{ns}$ & 0.023 & 0.169 & $\mathrm{~ns}$ & 0.012 & 0.024 \\
Slope $\ln (\mathrm{C}) / \mathrm{ln}(\mathrm{size})$ & $\mathrm{ns}$ & 2.79 & 4.25 & $\mathrm{~ns}$ & 2.44 & 3.05 \\
Slope ln(N)/ln(size) & $\mathrm{ns}$ & 2.75 & 7.05 & $\mathrm{~ns}$ & 2.4 & 2.68 \\
Slope egg/C & $\mathrm{ns}$ & -0.187 & $\mathrm{~ns}$ & $\mathrm{~ns}$ & $\mathrm{~ns}$ & 0.144 \\
Slope egg/N & 0.01 & -0.0087 & $\mathrm{~ns}$ & 0.01 & $\mathrm{~ns}$ & $\mathrm{~ns}$ \\
Slope egg/size & $\mathrm{ns}$ & $\mathrm{ns}$ & $\mathrm{ns}$ & $\mathrm{ns}$ & $\mathrm{ns}$ & $\mathrm{ns}$ \\
Slope egg/pf & 0.62 & 0.24 & 0.69 & 0.43 & - & - \\
\hline
\end{tabular}

Table 4. Calanus helgolandicus. Mean egg and fecal pellet production found in each experiment (number of eggs or faecal pellets $(\mathrm{Fp}) \mathrm{fem}^{-1} \mathrm{~d}^{-1}$ ), by taking into account either the first values of production (between Days 2 and 5), or those found at the end of the experiments (between Days 17 and 20). Values obtained on Day 1 were not considered because they did not reflect the food conditions used during the spawning experiments. CV: coefficient of variation

\begin{tabular}{|lcccccc|}
\hline Females & Days & $\mathrm{n}$ & $\begin{array}{c}\text { Eggs } \\
\text { fem }{ }^{-1} \mathrm{~d}^{-1}\end{array}$ & $\mathrm{CV}(\%)$ & $\begin{array}{c}\mathrm{Fp} \\
\text { fem }{ }^{-1} \mathrm{~d}^{-1}\end{array}$ & $\mathrm{CV}(\%)$ \\
\hline LL & 2 to 5 & 80 & 10.4 & 104.8 & 22.7 & 58.1 \\
$\mathrm{LH}$ & 17 to 20 & 68 & 4.1 & 123.5 & 16.2 & 47.7 \\
& 2 to 5 & 80 & 32.7 & 50.2 & 65.8 & 30.0 \\
$\mathrm{HH}$ & 17 to 20 & 50 & 20.6 & 68.6 & 46.3 & 49.5 \\
& 2 to 5 & 80 & 33.3 & 64.8 & 48.8 & 48.8 \\
$\mathrm{HL}$ & 17 to 20 & 75 & 35.5 & 72.3 & 43.6 & 59.7 \\
& 2 to 5 & 80 & 9.5 & 116.6 & 16.1 & 51.7 \\
& 17 to 20 & 75 & 4.1 & 125.5 & 23.6 & 42.7 \\
\hline
\end{tabular}

\section{Specific egg production rate and hatching success}

The specific egg production rate was calculated at the beginning (initial rate) and at the end (final rate) nificant. The values of egg production used to estimate the initial and final rates were those found between Days 2 to 5 and 17 to 20 (Table 4). Concerning the eight of the females, we used their initial and final concentration were lower than those found at the high To determine the structural egg pro-

To determine the structural egg production rate, the structural weight of the females was estimated using Eq. (2) (Table 5). Gonad weight was then deduced by considering the total weight minus the structural weight and the weight of the wax ester, which means that no statistics were feasible to compare gonad weights because they were not measured directly. However, it is remarkable to see how coherent the results were for gonad weight and egg production. Indeed, gonads were the heaviest in females held in or coming from high food concentration (Females HH, HL at the beginning and $\mathrm{HH}$, LH at the end). Females $\mathrm{HH}$, which were apparently producing the same number of eggs at the beginning and end of experiments, were also those maintaining almost the same gonad weight during the experiments (Table 5). Also, females coming from Cohort L had lower gonad weight at the end of experiments than that of females from cohort $\mathrm{H}(\mathrm{LH}<\mathrm{HH}, \mathrm{LL}<$ $\mathrm{HL})$, as was the case for the egg production (Table 4). Gonad weight was quite important since it varied between 11.5 and $48.6 \mu \mathrm{gC}$, which is a bit higher than that estimated for Calanus finmarchicus females by McLaren \& Leonard (1995) ( 30 $\mu \mathrm{g}$ C) and that provided by the model of Carlotti \& Hirche (1997) (5 to $30 \mu \mathrm{g} \mathrm{C}$ ). Because of the substantial difference between the total and the structural weight of the females, the specific egg production rates calculated from the struc- 


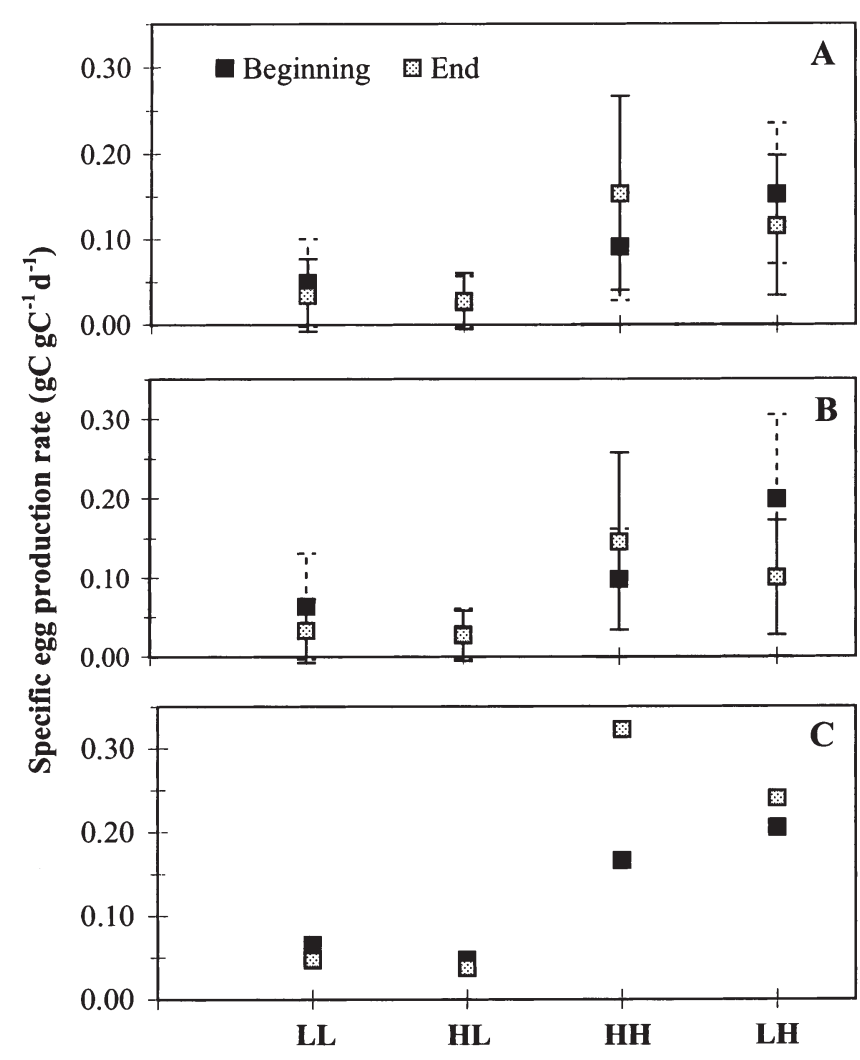

Fig. 4. Calanus helgolandicus. Specific egg production rate of

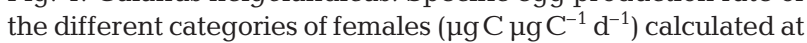
the beginning and end of each experiment. The rates are calculated from (A) carbon content, (B) nitrogen content and (C) structural weight of the females. Vertical bars are the standard deviation calculated for ratio (formula given by Takahashi \& Bienfang 1983; dashed line: beginning, solid line: end)

tural weight were markedly higher than those found from the total carbon weight (Fig. 4).

The hatching frequency of the eggs laid by each category of females during $1 \mathrm{~d}$ of the experiment is presented in Fig. 5. The hatching frequency was high in all experiments varying between 0.88 and 0.95 . However, when we compared the frequencies obtained in each experiment, we found that they were significantly different $\left(\chi^{2}\right.$-test, $\left.\mathrm{df}=3, \mathrm{p}<0.05\right)$, probably because the hatching frequency for the females held and raised at the low concentration (LL) was significantly lower than the other.

\section{Ingestion rate and gross egg production efficiency}

The ingestion rate measured at the beginning of the experiments was expressed either in terms of carbon or nitrogen (Table 6). The differences between the ingestion rates of the females incubated at the same concentration but from different cohorts were not significant.
Table 5. Calanus helgolandicus. Structural weight of the females (in $\mu \mathrm{g} \mathrm{C}$ ) at the beginning and at the end of each experiment. The structural weight was calculated from the relation established by Rey-Rassat et al. (2002; see the text). The gonad weight is the total carbon weight minus the structural weight and the lipids (lipids are only present in Females HL and $\mathrm{HH}$ at the beginning of experiments as shown in Table 2)

\begin{tabular}{|lccc|}
\hline Females & Period & Structural weight & Gonad weight \\
\hline LL & Beginning & 57.8 & 18.24 \\
& End & 31.8 & 11.49 \\
LH & Beginning & 57.8 & 18.24 \\
& End & 31.0 & 33.46 \\
$\mathrm{HH}$ & Beginning & 72.5 & 48.63 \\
& End & 39.9 & 44.05 \\
$\mathrm{HL}$ & Beginning & 72.5 & 48.63 \\
& End & 40.2 & 14.57 \\
\hline
\end{tabular}

However, when we consider the ingestion rate per unit of the female weight (specific ingestion rate), we found that the values of the females from Cohort $\mathrm{L}$ were higher $(74$ to $112 \%$ ) than for the Females $\mathrm{H}$ ( $\mathrm{LH}>\mathrm{HH}$ and LL > HL).

We also estimated the gross egg production efficiency of the females by considering the initial specific egg production rates (Fig. 4) divided by the specific ingestion rates (i.e. the ingestion rate divided by the initial weight of the females). Differences among gross egg production efficiencies were too low to be considered significant, but we can stress the fact that those calculated from the carbon data were always lower than those estimated on the basis of nitrogen.

\section{DISCUSSION}

\section{Influence of actual food concentration on females}

The actual nutritional conditions during the incubation of the females for egg production experiments

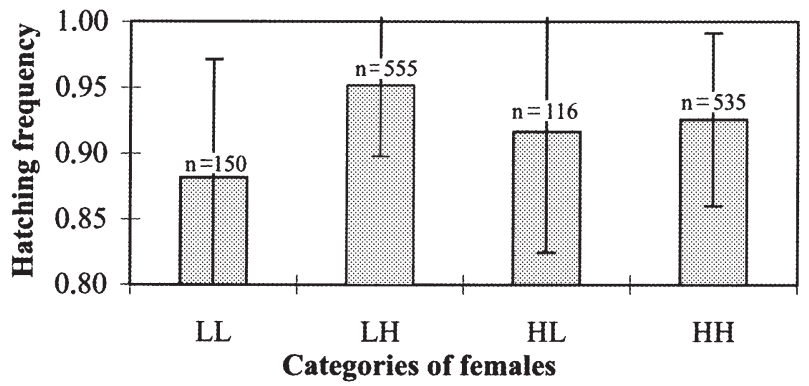

Fig. 5. Calanus helgolandicus. Frequency of hatching success calculated with the 4 categories of females (LL, LH, HL, HH). Vertical bars indicate SD. n: total number of eggs (hatched or not) considered for each category of females 
strongly influenced their physiology. The females incubated at the low food concentration (Females LL and HL) produced fewer eggs than those at the high concentration ( $\mathrm{HH}$ and $\mathrm{LH}$ ). This phenomenon is well known for the genus Calanus (Marshall \& Orr 1952, Frost 1985, Runge 1985, Peterson 1988, Hirche et al. 1997) even if it has never been studied in C. helgolandicus specifically. Moreover, despite the generally high hatching success, we found lower values for the eggs laid by the females held at the low concentration, which is in good agreement with Guisande \& Harris (1995). All these results can be directly related to the actual feeding of the females since the ingestion and egestion rates were much lower at the low concentration. C. helgolandicus is 1 species of the genus Calanus which can not spawn without a food supply, in contrast to C. hyperboreus or C. glacialis, which can produce eggs using only their stored lipid (Hirche \& Kattner 1993). In our study, it was clear that $C$. helgolandicus females also used internal body resources during experiments, and their loss in body carbon and nitrogen was greater for the females held at the low concentration (LL, HL, average of $46 \%$ ) than for those at the high concentration ( $\mathrm{HH}, \mathrm{LH}$, average of $14 \%)$. These internal resources were used to support different metabolic costs (egg synthesis included), which are impossible to evaluate separately. However, because the gonad of the females at low food concentration often reverted to an immature stage after laying eggs, these females may have to spend more energy (i.e. draw on their own body resources) to mature their gonad again before the next spawning event, compared with females at high food concentration, which remain mature between 2 spawning events (Runge 1984, Niehoff \& Hirche 1996, Niehoff et al. 1999).

Since a decrease in weight occurred for both females held at high and low food concentration, it may be that

Table 6. Calanus helgolandicus. Ingestion rate in terms of carbon and nitrogen ( $\mu \mathrm{g} \mathrm{C}$ or $\mu \mathrm{gN}$ ind.$^{-1} \mathrm{~d}^{-1}$ ) and gross egg production efficiency (GEE) of the females in the 4 experiments. The ingestion rate of the females incubated at the same high or low concentration is not found significantly different at the $5 \%$ level (Z-tests)

\begin{tabular}{|llll|}
\hline Females & & Ingestion rate & GEE \\
\hline LL & C & $20.5 \pm 3.8$ & 0.184 \\
& N & $2.80 \pm 0.52$ & 0.266 \\
LH & C & $54.6 \pm 9.5$ & 0.217 \\
& N & $7.46 \pm 1.29$ & 0.312 \\
HH & C & $65.1 \pm 6.9$ & 0.185 \\
& N & $8.90 \pm 0.94$ & 0.266 \\
HL & C & $20.1 \pm 4.4$ & 0.171 \\
& N & $2.74 \pm 0.60$ & 0.247 \\
\hline
\end{tabular}

the experimental conditions induced stress and increased the metabolic costs. In fact, this decrease is in contradiction with Hirche (1990) and Hirche \& Kattner (1993), who found no decrease and even an increase of the female body carbon after $77 \mathrm{~d}$ of spawning experiments at excess food. However, these differences in results might come from the use of a different species (Calanus finmarchicus and C. glacialis) and temperature $\left(\leq 0^{\circ} \mathrm{C}\right)$. The fact that in Hirche (1990) and Hirche \& Kattner (1993) the female weight was lower at the start of the experiments than at the end can also be due to the fact that females may have been food-limited at the time of collection or that they may have recently entered the stage, since, according to Rey-Rassat et al. (2002), the weight of females increases during the first days of the adult lifetime.

The gross egg production efficiency (GEE) measured at the beginning of the experiments and expressed in terms of carbon was always lower (17 to $22 \%$ ) than the GEE in terms of nitrogen (25 to $31 \%$ ). This suggests that the conversion of the egg production rate in terms of carbon into ingestion rate (by using the standard value of GEE $30 \%$ ) has to be considered with caution. Peterson (1988) found, for Calanus marshallae females, the GEE to be between 22 and $28 \%$ for food concentrations of 38 and $438 \mu \mathrm{g} \mathrm{C}^{-1}$, respectively. For this same relationship (GEE vs food), Båmstedt et al. (1999) found contradictory results because some indicated no significant relationship (their Fig. 9), whereas others suggested a positive one (their Fig. 12). In our case, the GEE was rather similar at both concentrations with, somehow, higher values at the highest concentration ( $\mathrm{HH}>\mathrm{HL}$ and LH > LL). More studies need to be performed to understand what the exact influence of food on the GEE is. Moreover, the GEE of the females was found to be lower than almost all the gross growth efficiency measured for each copepodite stage from the Cohorts H and L (Rey-Rassat et al. 2002). The decrease of the efficiency through the stages was also reported by Paffenhöfer (1976). The amount of carbon ingested and transferred to the eggs appears to be less important than for the somatic growth of the copepodites. This could come from the fact that the metabolism of the females is certainly higher than that of the copepodite stages because of higher energetic costs related to the functioning and the maintenance of the gonad.

\section{Influence of past feeding history on females}

The past feeding history of the females held at the low or high concentration during their spawning also strongly influenced a number of aspects of their physiology (Fig. 6). 
Weight

In females from Cohort $\mathrm{H}$, the loss in body carbon during experiments was similar to the loss in nitrogen (35\% for Females $\mathrm{HH}$ and $55 \%$ for Females HL), which was not the case in Females L that lost twice as much carbon as nitrogen. Results obtained for the Females $\mathrm{H}$ can be related to those of Mayzaud (1976), who showed that CV of Calanus finmarchicus were able to alternate between protein and lipid catabolism when needed. This was not the case for copepods without lipid storage such as Acartia sp., which was forced to draw on its protein resources until reaching the lethal protein threshold (Ikeda 1974, Mayzaud 1976). Our Females H, which catabolized the same relative amount of carbon and nitrogen, were using both their proteins and lipids to satisfy their energetic requirements. On the contrary, our Females L were certainly deficient in nitrogen components (e.g. in their protein resources) from the very beginning of the experiments, and they could not draw on these resources (Mayzaud 1976) as they would have been too close to the critical content in protein right from the beginning of the experiments. This would explain that, in the presence of an excess of food, the nitrogen content of the Females LH was the only one which increased during the experiments in order to rebuild the protein capital which had become depleted.

\section{Egestion}

Females from Cohort L had, for at least $5 \mathrm{~d}$, a much higher fecal pellet production than females from $\mathrm{H}$ (Figs. 1 \& 2). Interestingly, very similar results were obtained by Rey et al. (1999). These authors found that the egestion of Calanus finmarchicus females from a cohort reared under limiting food conditions was higher than that of females from a cohort reared under better food conditions; this phenomenon lasted for the 15 experimental d. However, the ingestion measured at the beginning of our spawning experiments was not influenced by the origin of the females. All these results suggest that the number of fecal pellets (fp) produced per unit of food ingested varied with the origin of the females (1.1 to $1.2 \mathrm{fp}$ for the Females LL and LH, 0.8 to 0.7 for the Females HL and $\mathrm{HH}$ ). There are 2 possible explanations for this: (1) The females from
Cohort L produced shorter (or less dense) fecal pellets than females from $\mathrm{H}$, but the total volume of fecal pellets produced by Females $\mathrm{L}$ and $\mathrm{H}$ was the same. Since we did not measure the fecal pellet volume, it is impossible to determine if this happened. However, we assumed this was not the case because Rey et al. (1999) found no significant difference between the volume of the fecal pellets produced by females from cohorts reared under high and low food conditions (see also Båmstedt et al. 1999). (2) The assimilation efficiency of Females L was initially lower than that of Females $\mathrm{H}$ (Fig. 6). This hypothesis would be in good agreement with the results of Mayzaud \& Conover (1976), Hirche (1981) and Tande \& Slagstad (1982), who showed a positive relationship between the nutritional conditions in the field and the digestive enzyme content of copepodites $\mathrm{CV}$ or females of $C$. finmarchicus and $C$. helgolandicus. Therefore, the enzymatic content of the copepods held at low concentration (as in Cohort L) would be lower than that of those at the high concentration (Cohort $\mathrm{H}$ ). However, we have to acknowledge that other authors have found inverse relationships (Hassett \& Landry 1983). Because we did not measure the enzymatic activity of the females in our experiments, it is impossible to make a definite conclusion. Nevertheless, we can note that the second hypothesis (i.e. low assimilation and low enzymatic activity for Females L) would be compatible with the fact that Females L were initially deficient in protein, as has been assumed previously. 


\section{Ingestion}

As we said before, ingestion rates were independent of the origin of the females. However, when considering the ingestion rate per unit of the female weight (specific ingestion rate), we found that the values of the females from Cohort L were higher (74 to $112 \%$ ) than for the females of Cohort $\mathrm{H}$. Such results can be related to those of Runge (1980), Hassett \& Landry $(1983,1990)$ and Frost (1985), who showed that the ingestion rates of Calanus pacificus females increased after they had been starved or submitted to very low food concentration for a certain period. High specific ingestion rates would permit the females from Cohort L to compensate for their low assimilation efficiency in order to optimize their spawning (Fig. 6).

\section{Egg production rate}

The females held at the same food concentration initially had the same egg production, whatever their origin. However, after a certain time into the experiment ( 7 to $10 \mathrm{~d}$ ), the egg production of females from Cohort $\mathrm{L}$ decreased and became significantly lower than that of Females $\mathrm{H}$ ( $\mathrm{LL}<\mathrm{HL}$ and $\mathrm{LH}<\mathrm{HH}$ ). This decrease is obviously related to smaller clutch size and longer intervals between clutch deposition as well as to the fact that a certain number of the Females L stopped spawning, and at the end of the experiments their gonads were found to be at an immature or senescent stage. The past feeding history of the females seems also to influence the hatching success since the eggs of Females LL had the lowest hatching success (LL $<\mathrm{LH}$, $\mathrm{HH}, \mathrm{HL}$ ). Following the previous paragraphs, we can assume that Females L could not maintain a maximal egg production rate because of the exhaustion of their metabolic reserves. By comparison with our Females L, the Calanus finmarchicus females coming from the Cohort L1 (reared at low food) in Rey et al. (1999) did not decrease their spawning during the $15 \mathrm{~d}$ of the experiment, which suggests that they may have succeeded in compensating for their initial deficiency (Fig. 6). The difference between the spawning vs time of our Females L and those (L1) described in Rey et al. (1999) certainly comes from the fact that the food condition was more limiting in the present case (average of $\left.80 \mu \mathrm{g} \mathrm{C} \mathrm{l}^{-1}\right)$ than in Rey et al. $\left(430 \mu \mathrm{gC} \mathrm{l}^{-1}\right)$, i.e. that the body deficiency was much greater in this study.

Even if Prorocentrum micans has been recognized as a nutrient of high quality (Hitchcock 1982, Rey et al. 2001), the mono-specific diet during all the development may have induced a nutritive deficiency. However, it is important to underline that the egg production values measured at the high concentration coincide perfectly with the maximal ones reported in laboratory and field studies on the same species (Gill \& Harris 1987, Bautista et al. 1994, Pond et al. 1996, Laabir et al. 1998, Biegala et al. 1999, Irigoien et al. 2000a).

Some authors suggest that copepods such as Females $\mathrm{L}$ are in fact rarely found in the field because they would be rapidly eliminated from the population (Huntley \& Lopez 1992, Aksnes 1996). It is certainly true that the lifetime in the case of the Females L could be shorter than that of the females which grew under optimal food conditions. However, it is rather difficult to imagine that females which grow under limiting food conditions are so rare in the field. They may represent a large part of the total females because the food conditions are unlikely to remain optimal during an entire generation. The patchy distribution of the food or mismatch between growth and phytoplankton blooms may also contribute to changes in the growing conditions of the females. Strong seasonal differences in the $\mathrm{C}: \mathrm{N}$ ratio of the females have been indicated by different authors suggesting differences in the growing conditions of the females (Tande 1982, Pond et al. 1996, Irigoien et al. 1998, 2000b). Therefore, it is likely that in the numerous field studies in which egg production was not found to be maximal considering the food and the temperature conditions, the feeding history of the females may have influenced their spawning (Bautista et al. 1994, Pond et al. 1996, Laabir et al. 1998, Irigoien et al. 2000a). These results indicate that the variability in the egg production rates found in field studies has to be interpreted cautiously, because it can be related not only to present or recent past conditions (food quantity, quality and temperature), but also to the growth history of the female.

\section{CONCLUSION}

In our experiments, the influence of the past and present feeding conditions on the egg production of Calanus helgolandicus females was investigated and we can conclude that: (1) the egg production was supported by the amount of food ingested but also by catabolism of body carbon and nitrogen resources; this catabolism was more important for females incubated at the low food concentration (LL, HL) than those at the high food concentration ( $\mathrm{HH}, \mathrm{LH}) ;(2)$ the catabolism also varied with the past feeding history of the females; while the percentage of loss of carbon during experiments was equal to that of nitrogen for females from Cohort $\mathrm{H}$ (i.e. $\mathrm{HH}$ and HL), twice as much carbon as compared to nitrogen was lost from females of Cohort L (LL and LH) suggesting that Females L could not draw as much on their protein resources because of 
an initial deficiency; and (3) the egg production of Females L after 7 to $10 \mathrm{~d}$ of experiments was significantly lower than that of Females $\mathrm{H}$, at both food concentrations ( $\mathrm{LL}<\mathrm{HL}$ and $\mathrm{LH}<\mathrm{HH}$ ); in other words, the past feeding history of females had a long-term effect on their egg production. Females L will experience a more rapid exhaustion of their internal resources compared with Females $\mathrm{H}$, and this will contribute to finally reducing their total fecundity.

Acknowledgements. This study was carried out as part of the Trans-Atlantic Study of the Calanus finmarchicus project (TASC) and was supported financially by the Commission of the European Community through contract MAS3-CT950039 (TASC) and the Plymouth Marine Laboratory. We thank J. Shepherd, Plymouth Marine Laboratory, for assistance with the egg counting.

\section{LITERATURE CITED}

Aksnes DL (1996) Natural mortality, fecundity and development time in marine planktonic copepods -implications of behaviour. Mar Ecol Prog Ser 131:315-316

Attwood CG, Peterson WT (1989) Reduction in fecundity and lipids of the copepod Calanus australis (Brodskii) by strongly pulsed upwelling. J Exp Mar Biol Ecol 129: 121-131

Båmstedt U (1988) Ecological significance of individual variability in copepod bioenergetics. Hydrobiologia 167-168: 43-59

Båmstedt U, Tande K (1988) Physiological responses of Calanus finmarchicus and Metridia longa (Copepoda: Calanoida) during the winter-spring transition. Mar Biol 99: $31-38$

Båmstedt U, Solberg PT, Nejstgaard JC (1999) Utilisation of small-sized food algae by Calanus finmarchicus (Copepoda: Calanoida) and the significance of feeding history. Sarsia 84:19-38

Bautista B, Harris RP, Rodriguez V, Guerrero F (1994) Temporal variability in copepod fecundity during two different spring bloom periods in coastal waters off Plymouth (SW England). J Plankton Res 16(10):1367-1377

Biegala IC, Harris RP, Bergeron JP (1999) ATCase activity, RNA:DNA ratio, gonad development stage, and egg production in the female copepod Calanus helgolandicus. Mar Biol 135:1-10

Calbet A, Agusti S (1999) Latitudinal changes of copepod egg production rates in Atlantic waters: temperature and food availability as the main driving factors. Mar Ecol Prog Ser 181:155-162

Carlotti F, Hirche HJ (1997) Growth and egg production of female Calanus finmarchicus: an individual-based physiological model and experimental validation. Mar Ecol Prog Ser 149:91-104

Donaghay PL (1988) Role of temporal scales of acclimation, food quality and trophic dominance in controlling the evolution of copepod feeding behavior. Bull Mar Sci 43(3): 469-485

Frost BW (1972) Effects of size and concentration of food particles on the feeding behavior of the marine planktonic copepod Calanus pacjficus. Limnol Oceanogr 17(6): 805-815

Frost BW (1985) Food limitation of the planktonic marine copepods Calanus pacificus and Pseudocalanus sp. in a temperate fjord. Arch Hydrobiol Beih Ergebn Limnol 21 $1-13$

Gill CW, Harris RP (1987) Behavioural responses of the copepods Calanus helgolandicus and Temora longicornis to dinoflagellate diets. J Mar Biol Assoc UK 67:785-801

Guisande C, Harris R (1995) Effect of total organic content of eggs on hatching success and naupliar survival in the copepod Calanus helgolandicus. Limnol Oceanogr 40(3): $476-482$

Harris RP, Irigoien X, Head RN, Rey C and 5 others (2000) Feeding, growth and reproduction in the genus Calanus. ICES J Mar Sci 57:1708-1726

Hassett RP, Landry MR (1983) Effects of food-level acclimation on digestive enzyme activities and feeding behaviour of Calanus pacificus. Mar Biol 75:47-55

Hassett RP, Landry MR (1990) Effects of diet and starvation on digestive enzyme activity and feeding behavior of the marine copepod Calanus pacificus. J Plankton Res 12(5): 991-1010

Hay S (1995) Egg production and secondary production of common North Sea copepods: field estimates with regional and seasonal comparisons. ICES J Mar Sci 52:315-327

Hirche HJ (1981) Digestive enzymes of copepodids and adults of Calanus finmarchicus and C. helgolandicus in relation to particulate matter. Kiel Meeresforsch 5:174-185

Hirche HJ (1990) Egg production of Calanus finmarchicus at low temperature. Mar Biol 106:53-58

Hirche HJ, Kattner G (1993) Egg production and lipid content of Calanus glacialis in spring: indication of a fooddependent and food-independent reproductive mode. Mar Biol 117:615-622

Hirche HJ, Meyer U, Niehoff B (1997) Egg production of Calanus finmarchicus-effect of temperature, food and season. Mar Biol 127:609-620

Hitchcock GL (1982) A comparative study of the sizedependent organic composition of marine diatoms and dinoflagellates. J Plankton Res 4(2):363-377

Huntley M (1988) Feeding biology of Calanus: a new perspective. Hydrobiologia 167-168:83-99

Huntley ME, Lopez MDG (1992) Temperature-dependent production of marine copepods: a global synthesis. Am Nat 140(2):201-242

Hygum BH, Rey C, Hansen BW, Tande K (2000) Importance of food quantity to structural growth rate and neutral lipid reserves accumulated in Calanus finmarchicus (Gunnerus). Mar Biol 136:1057-1074

Ikeda T (1974) Nutritional ecology of marine zooplankton. Mem Fac Fish Hokkaido Univ 22:1-97

Irigoien X, Head R, Klenke U, Niehoff B, Harris R, Hirche HJ (1998) A high frequency time series at Weathership $M$, Norwegian Sea, during the 1997 spring bloom: feeding of adult female Calanus finmarchicus. Mar Ecol Prog Ser 172:127-137

Irigoien X, Head RN, Harris RP, Cummings D, Harbour D, Meyer-Harms B (2000a) Feeding selectivity and egg production of Calanus helgolandicus in the English Channel. Limnol Oceanogr 45(1):44-54

Irigoien X, Harris RP, Head RN, Lindley JA, Harbour D (2000b) Physiology and population structure of Calanus finmarchicus (copepoda:calanoida) during a Lagrangian tracer release experiment in the North Atlantic. J Plankton Res 22:205-221

Irigoien X, Obermuller B, Head RN, Harris RP, Rey C, Hansen BW, Hygum BH, Durbin EG (2000c) On the sex ratio determination of Calanus. ICES J Mar Sci 57:1752-1763

Kiørboe T, Nielsen TG (1994) Regulation of zooplankton biomass and production in a temperate, coastal ecosystem. I. Copepods. Limnol Oceanogr 39(3):493-507 
Laabir M, Poulet SA, Harris RP, Pond DW, Cueff A, Head RN, Ianora A (1998) Comparative study of the reproduction of Calanus helgolandicus in well-mixed and seasonally stratified coastal waters of the western English Channel. J Plankton Res 20(3):407-421

Lopez MD (1991) Moulting and mortality depend on age and stage in naupliar Calanus pacificus: implication for development time of field cohorts. Mar Ecol Prog Ser 75:79-89

Marshall SM, Off AP (1952) On the biology of Calanus finmarchicus. VII. Factors affecting egg production. J Mar Biol Assoc UK 30:527-547

Mayzaud P (1976) Respiration and nitrogen excretion of zooplankton. IV. The influence of starvation on the metabolism and the biochemical composition of some species. Mar Biol 37:47-58

Mayzaud P, Conover RJ (1976) Influence of potential food supply on the activity of digestive enzymes of neritic zooplankton. In: Persoone G, Jaspers F (eds) Proc 10th Eur Mar Biol Symp, Vol 2. Universa Press, Wetteren, p 415-427

McLaren IA, Leonard A (1995) Assessing the equivalence of growth and egg production of copepods. ICES J Mar Sci 52:397-408

Miller CB, Morgan CA, Prahl FG, Sparrow MA (1998) Storage lipids of the copepod Calanus finmarchicus from Georges Bank and the Gulf of Maine. Limnol Oceanogr 43(3): 488-497

Niehoff B, Hirche HJ (1996) Oogenesis and gonad maturation in the copepod Calanus finmarchicus and the prediction of egg production from preserved samples. Polar Biol 16: 601-612

Niehoff B, Klenke U, Hirche HJ, Irigoien X, Head R, Harris R (1999) A high frequency time series at Weathership $M$, Norwegian Sea, during the 1997 spring bloom: the reproductive biology of Calanus finmarchicus. Mar Ecol Prog Ser 176:81-92

Nival S, Pagano M, Nival P (1990) Laboratory study of the spawning rate of the calanoid copepod Centropages typicus: effect of fluctuating food supply. J Plankton Res 12 : 535-547

Paffenhöfer GA (1976) Feeding, growth and food conversion of the marine planktonic copepod Calanus helgolandicus. Limnol Oceanogr 21(1):39-50

Peterson WT (1988) Rates of egg production by the copepod Calanus marshallae in the laboratory and in the sea off Oregon, USA. Mar Ecol Prog Ser 47:229-237

Peterson WT, Tiselius P, Kiørboe T (1991) Copepod egg production, moulting and growth rates, and secondary production, in the Skagerrak in August 1988. J Plankton Res 13(1):131-154

Editorial responsibility: Otto Kinne (Editor),

Oldendorf/Luhe, Germany
Plourde S, Runge JA (1993) Reproduction of the planktonic copepod Calanus finmarchicus in the Lower St. Lawrence Estuary: relation to the cycle of phytoplankton production and evidence for a Calanus pump. Mar Ecol Prog Ser 102: 217-227

Pond D, Harris R, Head R, Harbour D (1996) Environmental and nutritional factors determining seasonal variability in the fecundity and egg viability of Calanus helgolandicus in coastal waters off Plymouth, UK. Mar Ecol Prog Ser 143: $45-63$

Rey C, Carlotti F, Tande K, Hygum BH (1999) Egg and faecal pellet production of Calanus finmarchicus females from controlled mesocosms and in situ populations: influence of age and feeding history. Mar Ecol Prog Ser 188:133-148

Rey C, Harris R, Irigoien X, Head R, Carlotti F (2001) Influence of algal diet on growth and ingestion of Calanus helgolandicus nauplii. Mar Ecol Prog Ser 216:151-165

Rey-Rassat C, Irigoien X, Harris R, Head R, Carlotti F (2002) Growth and development of Calanus helgolandicus reared in the laboratory. Mar Ecol Prog Ser 238:125-138

Runge JA (1980) Effect of hunger and season on the feeding behavior of Calanus pacificus. Limnol Oceanogr 25(1): 134-145

Runge JA (1984) Egg production of the marine, planktonic copepod, Calanus pacificus Brodsky: laboratory observations. J Exp Mar Biol Ecol 74:53-66

Runge JA (1985) Egg production rates of Calanus finmarchicus in the sea off Nova Scotia. Ergeb Limnol 21:33-40

Runge JA (1987) Measurement of egg production rate of Calanus finmarchicus from preserved samples. Can J Fish Aquat Sci 44:2009-2012

Sargent JR, Henderson RJ (1986) Lipids. In: Corner ED, O'Hara SCM (eds) The biological chemistry of marine copepods. Clarendon, p 59-108

Takahashi M, Bienfang PK (1983) Size structure of phytoplankton biomass and photosynthesis in subtropical Hawaiian waters. Mar Biol 76:203-211

Tande KS (1982) Ecological investigations on the zooplankton community in Balsfjorden, northern Norway: Generation cycles, and variations in body weight and body content of carbon and nitrogen related to overwintering and reproduction in Calanus finmarchicus (Gunnerus). J Exp Mar Biol Ecol 62:129-142

Tande KS, Slagstad D (1982) Ecological investigations on the zooplankton community of Balsfjorden, northern Norway: seasonal and short-time variations in enzyme activity in copepodite Stage V and VI males and females of Calanus finmarchicus (Gunnerus). Sarsia 67(1):63-68

Tsuda A, Miller CB (1998) Mate-finding behavior in Calanus marshallae Frost. Phil Trans R Soc Lond B 353:713-720

Submitted: March 21, 2001 Accepted: February 26, 2002

Proofs received from author(s): July 18, 2002 